\title{
PEMAKNAAN KHALAYAK TERHADAP KONFLIK SELEBRITI PADA TAYANGAN INFOTAIMENT
}

\author{
Oleh: \\ Qudratullah \\ qudratullah@iain-bone.ac.id \\ Program Studi Komunikasi dan Penyiaran Islam \\ Institut Agama Islam Negeri (IAIN) Bone
}

\begin{abstract}
Infotainment news about artists that air on television is always unique and interesting to watch. This is caused by conflicts displayed on the television screen. To still be able to exist, celebrities carry out a strategy by creating a variety of controversial and behavioral behaviors which are then widely covered and broadcast by infotainment on television. The conflict news program carried out by these celebrities contained codes for each event. So this study tries to find out how the analysis of public receptions on the contents of messages in the reporting of celebrity conflicts in infotainment. This study uses a reception analysis method by conducting interviews with informants who have met certain criteria. The theory used is the EncodingDecoding Theory by Stuart Hall. The results show that there are 3 reception categories in celebrity conflict news on the audience. Four people in the Dominant Hegemonic category, one in the Negotiated category, and one in the Oppositional category.
\end{abstract}

Keywords: News, Celebrities, Infotainment, Reception Analysis, Encoding-Decoding. 


\begin{abstract}
Abstrak
Berita infotainment mengenai artis yang tayang di televisi selalu unik dan menarik untuk disimak.Hal ini disebabkan oleh konflik yang dipertontonkan di layar televisi.Untuk tetap bisa eksis, para selebriti melakukan strategi dengan menciptakan berbagai tingkah laku yang kontroversi dan feniomenal yang kemudian banyak diliput dan ditayangkan oleh infotainment di televisi.Tayangan berita konflik yang dilakukan para selebritiini mengandung kode-kode pada setiap peristiwanya.Maka penelitian ini berusaha mengetahui bagaimana analisis resepsi khalayak terhadap isi pesan pada pemberitaan konflik selebriti di infotainment.Penelitian ini menggunakan metode analisis resepsi dengan melakukan wawancara kepada informan yang telah memenuhi kriteria tertentu.Teori yang digunakan adalah Teori Encoding-Decoding oleh Stuart Hall.Hasil menunjukkan bahwa terdapat 3 kategori resepsi dalam berita konflik selebritipada penonton.Empat orang kategori Dominant Hegemonic, satu orang dalam kategori Negotiated, dan satu orang dalam kategori Oppositional.
\end{abstract}

Kata Kunci: Berita, Selebriti,Infotainment, Analisis Resepsi, Encoding-Decoding.

\title{
PENDAHULUAN
}

Kemajuan yang dialami manusia dengan ditandai denga hadirnya era globalisasi menjadikan informasi sebagai salah satu kebutuhan manusia saat ini. Dengan hadirnya media massa yang beragam, menjadikan informasi disajikan dengan beragam pula. Berbagai berita disebarluaskan melalui media massa, seperti media cetak, media elektronik dan media online. Media massa tersebut menyerbarluaskan berbagai macam berita, seperti berita ekonomi, berita politik, dan sebagainya.Sejauh ini, televisi masih menjadi media massa yang banyak digandrungi oleh masyarakat dibandingkan dengan radio, koran, tabloid, ataupun media online.

Hal tersebut terjadi karena televisi memberikan kemudahan jangkauan melalui frekuensi yang luas sehingga mudah dijangkau oleh penggunanya. Pengguna televisi juga hampir menyentuh seluruh lapisan masyarakat dalam berbagai tatanan tingkatan pendidikan, politik dan sosial budaya. Infotainment menjadi salah satu produk televisi yang banyak digandruni oleh khakayak saat ini. Beragamnya tayangan infotainment di televisi menjadi tolok ukur peminat infotainment.

Sejarah kemunculan infotainment sangatlah erat kaitannya dengan tabloidisasi.Tabloidisasi merupakan jurnalisme tabloid yang merepresentasikan informasi dan hiburan terkait dengan peristiwa, kehidupan terkini dari para pekerja seni yang sering disebut artis ataupun 
selebriti.Kemudian media televisi lebih lanjut membuat perkembangan infotainment menjadi lebih menarik dengan mentrasformasikan pola tabloidisasi dalam program infortainment yang berusaha mengajak khalayak untuk lebih dekat dan mengenal lebih banyak kehidupan para selebriti. ${ }^{1}$

Banyak kasus dari selebritis yang diangkat menjadi konsumsi publik baik itu kehidupan pribadi, konflik, perseteruan, skandal bahkan pencitraan terhadap selebritis itu sendiri.Berita mengenai konflik dari para selebriti tersebut mengundang perhatian khayalak untuk mengetaui secara mendalam mengenai konflik yang terjadi.

Tayangan infotainment menyampaikan teks-teks berita tentang informasi-informasi yang banyak mengarah pada kontroversi panjang para selebriti.Beritanya cenderung konfrontatif yang mempertentangkan dengan norma-normayang berlaku dalam kehidupan masyarakat.Dapur infotainment memberitakan kasus tersebut secara dramatisir dan penayangan secera bertubi-tubi setiap harinya.

Infotainment mengolah dan memberitakan para selebriti, di mana beragam berita kontroversi terus membanjiri layar televisi mengenai publik figur yang sedang ramai diperbincangkan. Tentunya hal tersebut semakin membuat khalayak tertarik dengan konflik yang terus-terus dipertontonkan. Dari tayangan tersebut, khalayak akan membaca dan menginterpretasikan teks yang disajikan oleh media melalui cara yang aktif. Khalayak mungkin menerima makna yang diberikan oleh media tetapi beberapa khalayak lainnya menggunakan ide dan pengalamannya untuk menegosiasikan makna mereka sendiri, bahkan ada yang menentang makna yang ingin disampaikan media.

Khalayak mempunyai kerangka acuan (frame of reference) yang akan mengarahkan pada pemahaman yang berbeda pula. Tiap individu berbeda, karena latar belakang pendidikan yang berbeda, riwayat hidup dan pengalaman yang berbeda, perbedaan sistem nilai dan norma, serta status pekerjaan yang berbeda pul. Setiap perbedaan ini membuat masing-masing individu berbeda pula dalam berpikir dan bertindak. Hal ini bisa membuat pesan yang sama diartikan berbeda oleh individu yang berbeda. Sehingga dalam penelitian ini akan dirumuskan bagaimana resepsi khalayak terhadap konflik selebriti dalam tayangan infotainment di televisi?

Tujuan penelitian ini adalah untuk mendeskripsikan bagaimana khalayak menerima perilaku selebriti dalam tayangan infotainment atas

${ }^{1}$ Hedi Pudjo Santosa, Menelisik Lika-Liku Infotainment di Media Televisi (Yogyakarta: Asa Media Prima, 2011), h. 9. 
pemberitaan konflik yang terjasi.Teori yang dipakai adalah teori encodingdecoding dari Stuart Hall dan menggunakan paradigma interpretif. ${ }^{2}$ subyek penelitian ini adalah teks-teks yang ada dalam tayangan konflik para selebriti di infotainment.

Khalayak dalam penelitian ini yaitu pemirsa yang secara rutin menyaksikan infotainment dengan kriteria perempuan usia 17 tahun ke atas dengan latar belakang pendidikan dan pekerjaan yang berbeda yang diharapkan akan muncul jawaban yang variatif. Analisis data dalam penelitian ini menggunakan Analisis resepsi memiliki cara pandang khusus tentang audiens atau dalam hal ini adalah pemirsa televisi di mana analisis resepsi memandang pemirsa sebagai "producer of meaning", bukan hanya sebagai konsumen dari isi media.

\section{METODE PENELITIAN}

Jenis penelitian ini adalah penelitian kualitatif dengan pendekatan metode analisis resepsi audience.Penelitian kualitatif adalah riset yang bertujuan untuk menjelaskan fenomena dengan sedalam-dalamnya melalui pengumpulan data sedalam-dalamnya. ${ }^{3}$ Penelitian ini menggunakan analisis resepsi yaitu analisis yang mendasarkan pada kesadaran atau cara subyek dalam menerima dan memahami obyek. Analisis resepsi dapat melihat mengapa khalayak memaknai sesuatu secara berbeda, faktorfaktor apa yang mempengaruhi perbedaan tersebut, dan konsekuensi sosial apakah yang muncul. ${ }^{4}$ (Billy, 2014 : 8). Analisis dalam penelitian ini akan dijabarkan secara deskriptif yang berarti peneliti akan membuat deskripsi secara sistematis, faktual, dan akurat tentang fakta-fakta dan sifat-sifat populasi atau objek. Penelitian ini mencoba untuk memaparkan realita yang terjadi dalam kehidupan social. ${ }^{5}$

Pendekatan metode analisis resepsi audience digunakan untuk mengungkap pesan atau makna dari pemberitaan konflik para selebritiyang

\footnotetext{
${ }^{2}$ Stephen W Littlejohn\& Karen A. Foss, Teori Komunikasi(Edisi 9; Jakarta: Salemba Humanika, 2009), h. 420

${ }^{3}$ Rachmat Kriyantono, Teknik Praktis Riset Komunikasi: Disertai Contoh Praktis Riset Media, Public Relation, Advertising, Komunikasi Organisaso, Komunikasi Pemasaran(Jakarta: Kencana, 2010), h. 56.

${ }^{4}$ Billy Susanti, "Analisis Resepsi Terhadap Rasisme dalam Film (Studi Analisis Resepsi Film 12 Years A Slave pada Mahasiswa Multi Etnis)” (Surakarta: Muhammadiyah Surakarta,2014), h. 8.

5 RachmatKriyantono, Teknik Praktis Riset Komunikasi: Disertai Contoh Praktis Riset Media, Public Relations, Advertising, Komunikasi Organisasi, Komunikasi Pemasaran (Jakarta: KencanaPrenada Media Group, 2007), h. 67-68.
} 
kemudian dimaknai oleh khalayak televisi.Khalayak dalam resepsi audience merupakan individu-individu yang memiliki berbagai macam latar belakang yang berbeda-beda, selain itu resepsi audience memandang khalayak memiliki peran aktif dalam menafsirkan pesan dari wacana program.Oleh karena itu, pesan yang di resepsi dari masing-masing individu pun berbeda-beda.Pada penelitian ini mengambil sampel enam informan yang memiliki latar belakang berbeda.Agar penelitian yang dilakukan fokus dan tidak meluas, peneliti memilih area di satu wilayah yaitu Semarang.Teknik analisis data dilakukan dengan tahap menyeleksi informan.Kemudian peneliti melakukan wawancara secara mendalam dengan informan yang telah dipilih.Kemudian peneliti menganalisis deskripsi dengan kategorisasi yang telah ditentukan, hingga akhirnya mengerucut pada hasil analisis dari informan dalam meresepsikan makna pemberitaan konflik selebriti pada infotainment.

\section{HASIL DAN PEMBAHASAN}

Jenis penelitian ini adalah penelitian kualitatif dengan pendekatan metode analisis resepsi audience.Khalayak dalam resepsi audience merupakan individu-individu yang memiliki berbagai macam latar belakang yang berbeda-beda (pendidikan maupun pekerjaan), selain itu resepsi audience memandang khalayak memiliki peran aktif dan memiliki power dalam menafsirkan pesan dari wacana program. Oleh karena itu, pesan yang di resepsi dari masing-masing individu pun berbeda-beda.

Pada penelitian ini mengambil sampel enam informan yang memiliki latar belakang berbeda. Agar penelitian yang dilakukan fokus dan tidak meluas, peneliti memilih area di Kota Makassar, selain itu Makassar juga merupakan ibukota Provinsi Sulawesi Selatan yang berpredikat sebagai provinsi kehidupan metropolitan tersbesar di Indonesia Timur. Kota Makassar tercatat dengan jumlah penduduk sebesar cukup banyak dengan usia produktif, yakni sekitar 18-64 tahun. Remaja dan dewasa sebagai bagian dari masyarakat yang berada pada umur produktif tersebut menjadi target potensial bagi industri infotaiment. Informan yang dipilih dalam penelitian ini ditentukan berdasarkan faktor yang memengaruhi pemaknaan pesan dalam pemberitaan yaitu, usia (18 tahun ke atas), dan jenis kelamin (perempuan dan laki-laki).

Mengambil tempat di satu wilayah, dimaksudkan untuk membingkai masyarakat yang akan dilakukan penelitian agar dapat melihat interpretasi masyarakat terhadap konten berita dengan berbagai latar belakang. Hal ini 
dapat digambarkan atau dijabarkan bahwa narasumber yang dipilih oleh peneliti adalah dewasa usia 18 tahun ke atas. Keenam infrorman yaitu Mahasiswa, Dokter, Pegawai Bank, Wiraswasta, Guru, dan Politisi. Alasan mengambil informan dari mahasiswa karena peneliti memandang Mahasiswa, Dokter, Pegawai Bank, Wiraswasta, Guru, dan Politisisebagai agen perubahan dan memiliki strata berpendidikan tinggi, dipandang mewakili sebagai individu bagian dari masyarakat umum yang merasakan berbagai kebijakan secara langsung, dari berbagai pendidikan dan pekerjaan hal ini diharapkan dapat memberikan persepsi dan pendapat dalam sudut pandang mereka pribadi atas pertanyaan yang diberikan oleh peneliti terkait dengan resepsi khalayak terhadap pemberitaan para selebriti melalui infotainment.

Informan pertama adalah Nunu 21 tahun (Mahasiswa), informan kedua adalah Iin 24 tahun (Dokter), informan ketiga Rezki Amalia, 27 tahun (Pegawai Bank), informan keempat Abrar, 25 tahun (Wiraswasta), informan kelima Marlia, 38 tahun (Guru), informan keenam Pratita, 25 tahun (Politisi).

Penelitian ini, berusaha mengeksplorasi analisis resepsi pemirsa tentang resepsi khalayak terhadap pemberitaan konflik selebriti melalui infotainment.Informan penelitian diperoleh melalui wawancara atau In-Dept Interview yang dilakukan terhadap narasumber yang menonton tayangan tersebut.Wawancara dilakukan secara langsung dengan para narasumber dengan tujuan untuk mengetahui pemaknaan, dan pendapat.

\section{Encoding}

Encoding merupakan awalan untuk memahi teori encoding decoding.Sebelum meneliti resepsi khalayak yang merupakan bagian dari tahap decoding, maka perlu diketahui makna yang ingin disampaikan melalui pemberitaan konflik selebriti dengan kode kekerasan dan pertentangan.Berita konflik selebriti dikemas sedemikian rupa sehingga mampu menarik penontonnya. Pemberitaan konflik selebriti tentunya akan banyak mengaitkan dengan kejadian-kejadian konflik pada umumnya.

\section{a. Tampilan Fisik}

Berita yang menampilkan konflik selebriti dengan pesan 'pertentangan' ditunjukkan melalui penampilan gerakan, ucapan dan ekspresi melalui tayangan infotainment.Penampilan gerakan seperti saling tunjukmenunjuk, bertengkar dan beradu argumen.Ucapan yang paling sering muncul dalam konflik yang terjadi oleh para selebriti adalah ucapan dengan nada yang 
tinggi dan saling menyalahkan. Ekspresi yang ditampilkan selebriti dalam konflik adalah ekspresi marah dan penuh amarah.

\section{Decoding}

a. Informan 1: Nunu 21 tahun (Mahasiswa)

Nunu berpendapat pemberitaan konflik selebriti merupakan kamuflase yaitu sebuah berita yang tidak menunjukkan produk sebenarnya, melainkan menyajikan sebuah pesan sebagai daya tarik agar menjadi isu sosial yang berkembang di masyarakat.Pemberitaan konflik selebriti melalui infotainment menggambarkan citra seseorang itu mampu berkamuflase tergantung pada situasi yang dihadapi.Maka khalayak disarankan untuk mampu memilih informasi yang lebih baik.

Nunu menyatakan setuju dengan isi berita mengenai selebriti yang memuat konflik laki-laki dan perempuan. Di mana laki-laki memang seharusnya mengalah. Nunu tidak tertarik untuk mencari tahuberita kontroversi para selebritikarena secara prinsip dia akan tertarik karena pengemasan berita yang lebih edukatif, kadang produk media yang pasti akan lebih berdampak baik daripada yang hanya orientasi eksistensi semata.

b. Informan 2: Iin 24 tahun (Dokter) konflik selebriti dikemas dengan menarik, isi dalam berita tersbutkarena langsung memperlihatkan adegan konflik yang kemudian diakhiri dengan perdamaian.Tetapi diselipkan katakata yang ada hubungannya dengan sindiran.Meskipun setiap orang dapat mempersepsikan kata-kata tersebut dengan berbeda-beda.

Berita konflik selebriti bermakna berbohong boleh untuk menyenangkan hati orang lain. Dalam isi pesanberita konflik selebriti,Iin mengatakan setuju untuk mengalah, jika keadaan terdesak dan mengharuskan kita untuk tidak bisa berkata yang sebenarnya.Meskipun berbohong itu salah namun apabila itu membuat orang senang dan bahagia tidak menjadi sebuah masalah.Karena bagi Iin kenyamanan dalam sebuah kehidupan merupakan hal utama. Kenyamanan bagi diri kita, teman, saudara apalagi dengan keluarga semua akan indah jika rasa nyaman itu telah tercipta dari awal sampai akhir cerita meskipun ada halangan cobaan serta rintangan yang terus selalu ada.

\section{c. Informan 3:Rezki Amalia, 27 tahun, (Pegawai Bank)}

Rezki Amalia berpendapat bahwa tayangan di infotainment secara visual bagus karena tidak langsung memperlihatkan orang yang konflik. 
Berita konflik selebriti mengajarkan bahwa hidup selalu rasional dan selebriti khususnya wanita itu selalu ingin diperlakukan dengan penuh kelembutan.

Rezki Amalia mengatakan setuju dalam isi pemberitaan konflik selebriti karena ada masa-masadi mana orang perlu diperlihatkan apa yang terjadi sebenarnya. Dia mengatakan bahwa pesan informatifnya tidak ada. Bahasa lisan (verbal) yang digunakan dalam berita konflik selebriti,beritanya mengacu pada konflik pertentangan semata yang kadang-kadang berakhir damai.

\section{d. Informan IV, Abrar, 25 tahun (Wiraswasta)}

Abrar berpendapat bahwa tayangan berita konflik selebriti yang banyak tayang di infotainment tersebut selalu memiliki pesan tersembunyi di dalamnya tentang sikap, cara pandang, dan perjuangan seorang untuk melakukan apapun buat mendapat keperpihakan. Tayangan berita konflik selebritimenggambarkan cara bersikap seseorang yang tegas. Abrar mengatakan setuju dengan beritakonflik selebritikarena seorang harus bisa menempatkan dirinya untuk tetep bisa membuat orang lain senang atau tidak membuatnya kecewa.

\section{e. Informan V, Marlia, 38 tahun (Guru)}

Marlia berpendapat bahwa tayangan berita konflikselebrititidak menunjukkan keharmonisan yang dirasakan yang menjadi ending dalam tayangan,, tetapi disisi lain lebih menampilkan beberapa pihak yang mengalah dan berdamai. Berita tersebut sebenarnya tidak menunjukkan realitas selebriti melainkan menunjukkan realitas media.

Marlia mengatakan tidak setuju, berita tersebut tidak menunjukkan kelebihan dari selebriti itu sendiri.Bahasa verbal (lisan) yang digunakan berita itu menurut Marlia bahwa pihakyang mengalah punya kepribadian seperti yang ditampilkan tayangan infotainment harus berbuat negatif demi kebenaran.

\section{f. Informan VI, Pratita, 27 tahun (Politisi)}

Pratita berpendapat bahwa secara general pendapat tentang beberapa tayangan infotainment mengenai mengenai konflik yang pernah dia dilihat selalu kontroversi, karena selalu ada makna tersirat yang positif seperti yang menonjolkan tentang sosok selebriti, tentang keberanian menggapai mimpi dalam mengambil resiko, dan lain-lain. 
Dari rangkaian pemahaman yang disampaikan informan, dapat terlihat bagaimana mereka melakukan pemaknaan terhadap konflik selebriti di infotainment. Meskipun dengan teks yang sama yang ditawarkan kepada informan, namun muncul berbagai tipe pemaknaan yang beragam. Hal ini karena cara pandang masing-masing informan yang berbeda-beda dalam memaknai teks. Berangkat dari pemaknaan khalayak yang belum tentu sejalan dengan makna dominan yang ditawarkan media, maka Stuart Hall dalam Storeymenyebut ada tiga posisi pemaknaan atau decoding terhadap wacana televisual bisa dibangun, yakni posisi dominan-hegemonik, kode atau posisi yang dinegosiasikan, dan kode oposisional. ${ }^{6}$

Pada penelitian ini, peneliti ingin mengetahui pemaknaan khalayak terhadap isi pesan tayangan infotainment tentang konflik selebritidengan menggunakan metode analisis resepsi untuk mengungkapkan makna yang timbul dalam masyarakat akibat tayangan tersebut dan mengkategorikannya ke dalam tiga kategorisasi dari pemaknaan pembacaan khalayak terhadap teks media yaitu Dominant Hegemonic, Negotiated Reading, dan Oppositional Position.

\section{a. Dominant Hegemonic}

Informan memberikan resepsi secara keseluruhan mengenai berita konflik selebriti. Penerimaan ini dilakukan ke empat informan menilai secara keseluruhan memiliki pesan moral yang ditunjukkan dengan jelas pada tayangan tersebut. Informan Mahasiswa, Dokter, Pegawai Bank, dan Wiraswasta berada pada posisi Dominant Hegemonic yang menyatakan bahwa tayangan infotainment dikemas dengan menarik, isi dalam berita tersebut tidak langsung memperlihatkan adegan anarkis atau pertengkatan. Tetapi biasanya diselipkan kata-kata yang ada hubungannya dengan sindiran.Meskipun setiap orang dapat mempersepsikan kata-kata tersebut dengan berbeda-beda.

Informan Mahasiswa, Dokter, Pegawai Bank, dan Wiraswasta, Guru dan Politisi, mengatakan bahwa berita tayangan infotainment konflik selebriti menggunakan bahasa verbal (lisan) kiasan dalam arti mengacu pada cara pandang selebriti yang mampu menempatkan diri dalam kondisi yang tepat, walaupun harus melalukan sesuatu yang tidak sesuai dengan apa adanya.

Dari berita yang ditampilkan, informan Mahasiswa, Dokter, Pegawai Bank, dan Wiraswasta membenarkan atau setuju tema yang diangkat dalam

\footnotetext{
${ }^{6}$ JohnStorey,Cultural Studies dan Kajian Budaya Pop (Yogyakarta: Jalasutra, 2010), h. 16-18.
} 
tayangan tersebut. Menggambarkan kejadian dalam kehidupan yang nyata terjadi.Realitas yang terjadi seperti halnya banyak pihak berbohong.

b. Negoteatid Reading

Informan VI (Politisi) ini berada pada posisi Negoteatid karena dia berpendapat bahwa Kurang setuju dalam isi pesan tayangan berita konflik selebrititersebut karena ada pihak memilih untuk jujur daripada dibohongi.

\section{c. Oppositional Reading}

Informan Guru berada dalam kategori Oppositional Reading, menyatakan bahwa isi pesan berita tidak setuju, karena berita tidak menunjukkan kelebihan darisosok sebeliriti itu sendiri.

Hasil analisis decoding yang dilakukan oleh enam informan terhadap tayangan berita konflik selebritimenunjukkan bahwa empat informan masuk dalam kategori Dominant Hegemonic, satu informan dalam Negotiated Reading, dan satu informan dalam kategori Oppositional Reading.

\section{PENUTUP}

Hasil penelitian ini menunjukkan bahwa pada Dominant Hegemonic , informan Mahasiswa, Dokter, Pegawai Bank, dan Wiraswasta membenarkan atau setuju tema yang diangkat dalam tayangan tersebut. Menggambarkan kejadian dalam kehidupan yang nyata terjadi.Realitas yang terjadi seperti halnya banyak pihak yang berbohonh.Negoteatid Reading, Informan VI (Politisi) ini berada pada posisi Negoteatid karena dia berpendapat bahwa Kurang setuju dalam isi pesan tayangan berita konflik selebrititersebut karena pihak lain memilih untuk jujur daripada dibohongi. Oppositional Reading, Informan Guru berada dalam kategori Oppositional Reading, menyatakan bahwa isi pesan berita tidak setuju, karena berita tidak menunjukkan kelebihan dari sosok artis itu sendiri. Hasil analisis decoding yang dilakukan oleh enam informan terhadap tayangan berita konflik seleberiti menunjukkan bahwa empat informan masuk dalam kategori Dominant Hegemonic, satu informan dalam Negotiated Reading, dan satu informan dalam kategori Oppositional Reading. 


\section{DAFTAR PUSTAKA}

Billy Susanti, "Analisis Resepsi Terhadap Rasisme dalam Film (Studi Analisis Resepsi Film 12 Years A Slave pada Mahasiswa Multi Etnis).Surakarta: Muhammadiyah Surakarta.2014.

Hedi Pudjo Santosa. Menelisik Lika-Liku Infotainment di Media Televisi. Yogyakarta: Asa Media Prima. 2011.

Kriyantono, Rachmat, Teknik Praktis Riset Komunikasi: Disertai Contoh Praktis Riset Media, Public Relation, Advertising, Komunikasi Organisaso, Komunikasi Pemasaran. Jakarta: Kencana, 2010.

Kriyantono, Rachmat. Teknik Praktis Riset Komunikasi: Disertai Contoh Praktis Riset Media, Public Relations, Advertising, Komunikasi Organisasi, Komunikasi Pemasaran. Jakarta: KencanaPrenada Media Group.2007.

Littlejohn, Stephen W \& Karen A. Foss, Teori Komunikasi. Edisi9.Jakarta: Salemba Humanika. 2009.

Storey,John.Cultural Studies dan Kajian Budaya Pop.Yogyakarta: Jalasutra.2010. 